\section{Survival and Growth of Wildflowers with Buffalo Grass or Blue Grama Grass}

\author{
Dale T. Lindgren ${ }^{1}$ and Daniel Schaaf ${ }^{2}$ \\ University of Nebraska West Central Research and Extension Center, 461 West \\ University Drive, North Platte, NE 69101-7756
}

Additional index words. forbs, Buchloe dactyloides, Bouteloua gracilis

\begin{abstract}
Two studies in west-central Nebraska to determine the survival of wildflowers planted with buffalo grass [Buchloe dactyloides (Nutt.) Engelm.] and blue grama grass [Bouteloua gracilis (H.B.K.) Lag. ex Steud.)] were conducted in 6 and 10 year studies. In total, 19 forbs and 1 grass were transplanted with 'Texoka' buffalo grass in the first study, and 16 forbs were planted in a split-plot design into 3 buffalo grass selections, blue grama or a clean cultivated plot in the second study. Survival between transplants in both studies varied significantly. In the first study, survival was significantly higher for little bluestem (Schizachyrium scoparium Michx.) (85\%), bouncing bet (Saponaria officinalis L.) (100\%), and stiff goldenrod (Solidago rigida $\mathrm{L}$.) $(100 \%)$ over the 6 years of the study. In the second study, there were significant differences between species for survival, with grayhead prairie coneflower [Ratibida pinnata (Vent.) Barnh.] (85\%) and pitcher sage (Salvia azurea Lam.) $(80 \%)$ having the highest survival at the end of the 10-year study. There were significant differences in height and number of flower stalks within $S$. rigida, $R$. pinnata, and $S$. azurea between years and between main plots. This study demonstrates differences in survival and growth of wildflowers when planted in conjunction with buffalo grass and blue grama grass.
\end{abstract}

Prairie plantings that incorporate grasses and forbs are increasing in popularity formaintenance and aesthetic reasons (Todd, 2005). There are numerous benefits and issues involved in establishing and designing with wildflowers(Aldrich, 2002). Seeding wildflowers into established grasses can result in their poor establishment in that established plants often have a competitive survival advantage over plants introduced later (Zajiceketal., 1986). Withmini-prairie plantings and wildflowergrass plantings, establishing forbs and grasses using transplants has the advantage of more precise control of plant placement and spacing, improved establishment and survival, and easier weed control (Grantz et al., 1998). Incorporating wildflowers with the shorter-growing warm-season grasses, like buffalo grass [Buchloe dactyloides (Nutt.) Engelm.] and blue grama, [Bouteloua gracilis (H.B.K.) Lag. ex Steud.)] has the potential to result in an attractive prairie planting with aesthetically pleasing wildflowers. However, with these plantings, grasses and forbs need to complement each other aesthetically, environmentally, and competitively (Salac et al., 1978; Stubbendieck et al., 1985).

Two studies were conducted to evaluate the survival and growth of native plants or wildflowers in warm-season grasses in westcentral Nebraska.

\section{Materials and Methods}

The two studies, one initiated in 1990 and

Received for publication 15 Feb. 2005. Accepted for publication 5 Apr. 2005. A contribution of the University of Nebraska Agricultural Research Division, Lincoln, NE 68583. Journal Series No. 14490. This research was supported in part by funds provided through the Hatch Act under projects No. NEB 43-047 and NEB 43-066.

'Professor; to whom reprint requests should be addressed; e-mail dlindgren1@unl.edu.

${ }^{2}$ Research technician. one in 1991, were planted in field plots at the University of Nebraska West Central Research and Extension Center near North Platte, Nebr. In both studies, wildflowers were started from seed in a greenhouse and transplanted to the field research plots with a Cozad silt loam (fine-silty, mixed, mesic Fluventic Haplustoll), $\mathrm{pH}$ of 7.6. Transplants were 5 to $8 \mathrm{~cm}$ tall at the time of transplanting. No fertilizer was applied to the plots. Plots were mowed to a height of $5.2 \mathrm{~cm}$ in April of each year. All treatments in both studies were replicated 4 times.

In the first study, 19 species of wildflowers and one grass, little bluestem, were transplanted on 3 May 1990 with five plants of each species planted in a $60 \times 300 \mathrm{~cm}$ area, with plants spaced $60 \mathrm{~cm}$ apart, lengthwise in the center of the plots (Table 1). Two weeks later, plugs $2 \mathrm{~cm}$ in diameter of 'Texoka' buffalo grass were replanted from a field planting at $30-\mathrm{cm}$ intervals throughout the entire study. Plots were hand weeded weekly until the buffalo grass had spread to fully cover the plots. For each plot, survival of the transplanted wildflowers was recorded in October 1991 and then the first week of June for each year through 1996.

In the second study, established in 1991, 16 plots consisting of three buffalo grass cultivars, one blue grama grass, and one blank, which contained no grass. Each subplot was $60 \times 300$ $\mathrm{cm}$ with five transplants of each forb planted $60 \mathrm{~cm}$ apart in the center of each subplot. The three buffalo grass subplots were planted from plugs $2 \mathrm{~cm}$ in diameter, and the blue grama subplots were established from seeds. The blue grama was seeded, and the buffalo grass plugs were set out one day after the forbs were transplanted to the subplots. The blank plots contained only transplanted forbs and were hand weeded weekly the first year. The three buffalo grass cultivars used were 'Texoka', '378', and ' 315 '. 'Texoka' is a forage type buffalo grass forbs (Table 2) were transplanted to five sub- and '378' and '315' (Riordan et al., 1995) are turf-type buffalo grasses. The blue grama seed came from a South Dakota source of unknown origin. The 16 forbs were monitored for survival each year from 1992 to 2001 . Survival was based on the percentage of plants alive in early June. In addition, three of the native plants, Solidago rigida, Salvia azurea, and Ratibida pinnata, were measured from 1992 to 1997 for height and for the number of flower stalks per plant. Other selections in the second study were not included in this comparison because of the amount of missing data due to low survival.

Supplemental water was applied so that plots in both studies received at least $2.5 \mathrm{~cm}$ of water a week for the first 4 weeks until the forbs and buffalo grass were established. Thereafter, no additional irrigation was provided above rainfall. Data for both studies were analyzed with the SAS statistical analysis system using the Proc Mixed procedure (SAS Institute, 1999).

\section{Results and Discussion}

There were highly significant differences between plant species, between years, and years $\times$ plant interaction for survival in the first study (Table 1). Survival was lower for Liatris punctata Hook. (dotted gayfeather), Asclepias tuberosa L. (butterfly milkweed), and Penstemon angustifolius Nutt. ex Pursh (narrow beardtongue) during the first 2 years (Table 1). These species each had a smaller and poorer developed root system when transplanted, which may have contributed to the low initial establishment and survival. Rodents especially liked the corms and roots of $L$. punctata, which contributed to the poor survival of this species. At the end of 6 years, $S$. scoparium (littlebluestem), Liatris pycnostachya Michx. (tall gayfeather), Saponaria officinalis L. (bouncing bet), and S. rigida (rigid goldenrod) had the highest survival. Although $S$. officinalis survived well, it was considered aggressive because as it spread, it choked out the buffalo grass. Little bluestem, the only grass in the study, had an $85 \%$ survival rate at the end of 6 years and also reseeded in the plots.

In the second study, survival was highest for $R$. pinnata and S. azurea, and S. rigida had intermediate survival at the end of 10 years (Table 2). The higher survival of $S$. azurea agrees with data presented in a study by Thomas and Schrock (2004). Survival for plants of Echinacea angustifolius DC. (blacksamson), Ceratoides lanata (Pursh) Howell (winter fat), L. punctata, and Liatris squarrosa (L.) Michx. (rattlesnakemaster) was intermediate to low (17\% to $23 \%)$, and survival of L. pycnostachya and Penstemon 'Prairie Splendor' was very low (2\% to 6\%). Seven of the test species had zero survival at the end of 10 years. The statistical analysis (Table 2) suggests that there were no significant differences in survival between subplots (grass) and the grass $\times$ species interaction. Some plants such as Lithospermum incisum Lehm. (hoary puccoon) and Penstemon grandiflorus Nutt. are considered short-lived perennials so their survival of 3 to 5 years was not unexpected (Lindgren and Wilde, 2003). The results of survival of $S$. azurea and P. grandiflorus agree with those of Thomas and Schrock (2004). 
There were also highly significant differences in height and in the number of flower stalks for $R$. pinnata, $S$. rigida, and $S$. azurea in the second study. In 1996, the number of flower stalks was lower for $R$. pinnata and $S$. rigida compared to previous years (Tables 3 and 4). However, in the same year, stalk numbers were higher for $S$. azurea than in the other years (Table 5). Growing conditions and plant adaptation or response affect growth differently for different species over the years. In general, the three species were taller and had more flower stalks when growing in no competition (blank treatment) than with grass, as would be expected. Overall, the height and the number of stalks per plant for $R$. pinnata and S. rigida decreased from 1992 to 1997 in all five of the treatments.

The studies suggest that some species survive for much longer than others in warm-season grasses like buffalo grass or blue grama. For example, A. tuberosa L. survival was low initially, whereas plants like $P$. grandiflorus had a gradual decline in survival over years, and some plants, such as Antennaria neglecta Greene and Penstemon strictus Benth. (Rocky Mountain penstemon) survived well for a few years but then survival decreased sharply (Table 1). Echinacea purpurea (L.) Moench. (purple coneflower) also had a sharp decrease in survival in both studies. Salvia azurea and $R$. pinnata both had good survival throughout the second study whereas
L. punctata started low in numbers but remained steady, suggesting that once established, some species survive well. Salvia azurea is reported to have a rooting depth of 6 to 8 feet, and $S$. rigida has a rooting depth of $>5$ feet, which may explain why they survived well in these studies (Phillips Petroleum Co., 1959). Other factors such as height, reseeding, aesthetics, scale of plants to one another, and plant combinations also need to be considered in establishing of wildflower plantings (Todd, 2005). The short warm-season grasses are, in general, not considered shade tolerant of taller forbs and grasses so that taller plants probably have a competitive advantage. Recommended species to use as transplants in short warm-season grasses, based on survival and

Table 1. Survival of 20 selections of native plants grown in buffalo grass for 6 years. All plants were established in 1990.

\begin{tabular}{|c|c|c|c|c|c|c|}
\hline \multirow[b]{2}{*}{ Name of plant in study } & \multicolumn{6}{|c|}{ Survival (\%) } \\
\hline & 1991 & 1992 & 1993 & 1994 & 1995 & 1996 \\
\hline Asclepias tuberosa L. (butterfly milkweed) & 35.0 & 15.0 & 5.0 & 0.0 & 0.0 & 0.0 \\
\hline Echinacea pallida (Nutt.) Nutt. (pale purple coneflower) & 100.0 & 100.0 & 85.0 & 80.0 & 70.0 & 30.0 \\
\hline Echinacea purpurea (L.) Moench.(purple coneflower) & 95.0 & 95.0 & 30.0 & 10.0 & 0.0 & 0.0 \\
\hline Liatris punctata Hook. (dotted gayfeather) & 55.0 & 25.0 & 0.0 & 0.0 & 0.0 & 0.0 \\
\hline Penstemon $\times$ 'Prairie Splendor' & 100.0 & 80.0 & 40.0 & 10.0 & 0.0 & 0.0 \\
\hline Penstemon angustifolius Nutt. ex Pursh (narrow beardtongue) & 100.0 & 20.0 & 0.0 & 0.0 & 0.0 & 0.0 \\
\hline Penstemon barbatus (Cav.) Roth (scarlet burgler) & 100.0 & 55.0 & 20.0 & 0.0 & 0.0 & 0.0 \\
\hline Penstemon digitalis Nutt. ex Sims (smooth beardtongue) & 100.0 & 90.0 & 90.0 & 55.0 & 45.0 & 0.0 \\
\hline Penstemon gracilis Nutt. (slender beardtongue) & 85.0 & 75.0 & 65.0 & 40.0 & 25.0 & 10.0 \\
\hline Penstemon grandiflorus Nutt. (large beardtongue) & 90.0 & 75.0 & 45.0 & 10.0 & 5.0 & 0.0 \\
\hline Penstemon strictus Benth. (rocky mountain penstemon) & 100.0 & 95.0 & 90.0 & 80.0 & 65.0 & 0.0 \\
\hline $\operatorname{LSD}(P \leq 0.05)$ & 16.4 & 22.4 & 26.3 & 26.8 & 23.0 & 28.2 \\
\hline
\end{tabular}

\begin{tabular}{lrrr} 
Source & df & F value & $P$ \\
\hline Year & 5 & 277.33 & $* *$ \\
Plant & 19 & 96.87 & $* *$ \\
Year $\times$ plant & 95 & 7.15 & $* *$
\end{tabular}

${ }^{* * *}$ Significant at $P \leq 0.01$, respectively.

Table 2. Survival of 16 species of native plants averaged over all treatments for 10 years. ${ }^{2}$

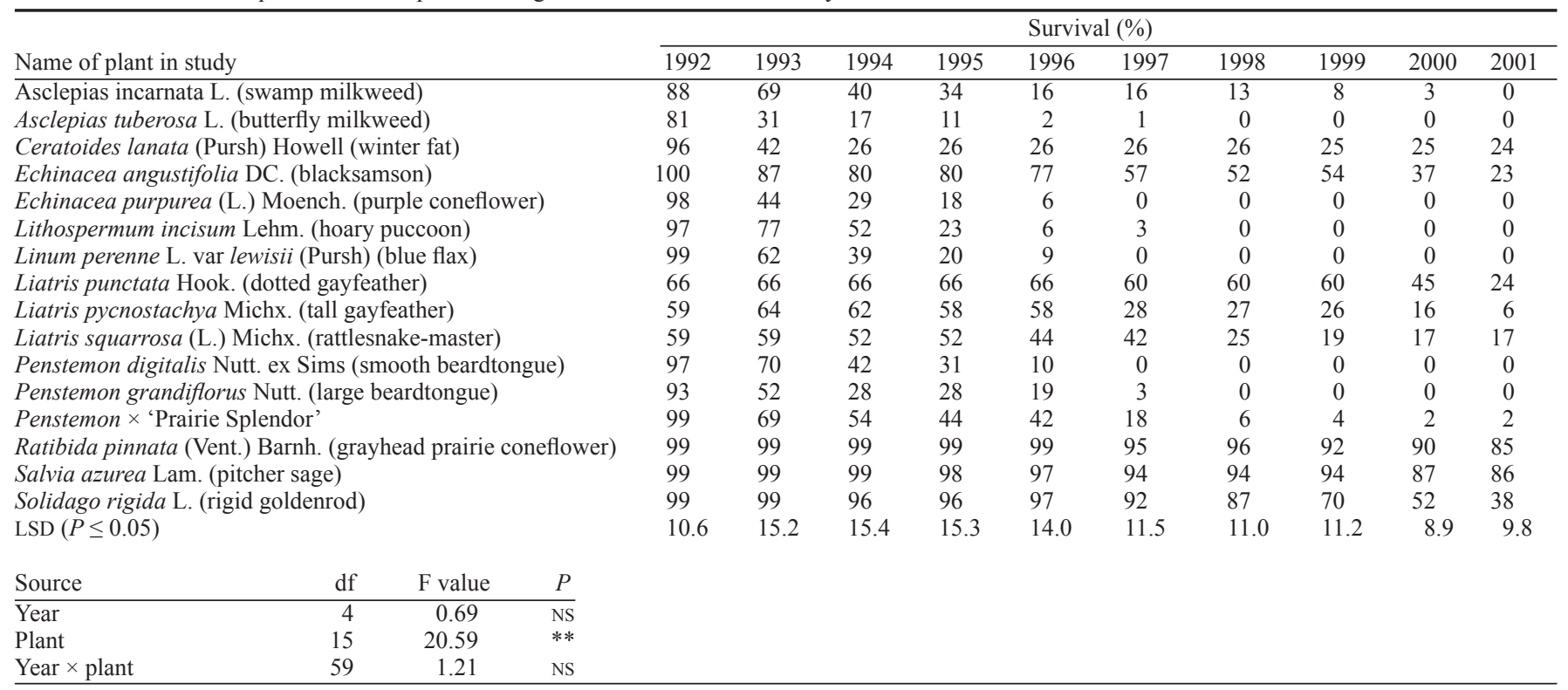

${ }^{2}$ All plants were established in May 1991 .

NS, ${ }^{* *}$ Nonsignificant or significant at $P \leq 0.01$, respectively. 
Table 3. Height and number of flower stalks of Ratibida pinnata (Vent.) Barnh. from 1992 to 1997.

\begin{tabular}{|c|c|c|c|c|c|c|c|c|}
\hline \multicolumn{3}{|c|}{ Plot treatment and trait measured } & 1992 & 1993 & 1994 & 1995 & 1996 & 1997 \\
\hline \multirow[t]{2}{*}{ 'Texoka' } & Height (cm) & & 116 & 119 & 97 & 97 & 89 & 93 \\
\hline & Stalk no. & & 45.1 & 27.4 & 29.8 & 19.7 & 5.0 & 19.4 \\
\hline \multirow[t]{2}{*}{ ' 378 ' } & Height (cm) & & 114 & 112 & 92 & 95 & 79 & 85 \\
\hline & Stalk no. & & 42.5 & 28.3 & 29.1 & 17.9 & 4.3 & 12.8 \\
\hline \multirow[t]{2}{*}{ ' $315^{\prime}$} & Height (cm) & & 119 & 96 & 90 & 89 & 82 & 86 \\
\hline & Stalk no. & & 45.9 & 25.5 & 18.4 & 12.9 & 4.3 & 14.7 \\
\hline \multicolumn{6}{|l|}{ Blue grama } & 99 & 93 & 85 \\
\hline \multirow{3}{*}{ Blank } & Stalk no. & & 33.4 & 26.6 & 20.0 & 14.9 & 6.0 & 10.6 \\
\hline & Height $(\mathrm{cm})$ & & 129 & 119 & 112 & 112 & 101 & 98 \\
\hline & Stalk no. & & 72.4 & 23.2 & 59.5 & 39.0 & 9.0 & 33.9 \\
\hline Source & Flower stalk no. & $\mathrm{Ht}$ & & & & & & \\
\hline Year & $* *$ & $* *$ & & & & & & \\
\hline Grass & $* *$ & $* *$ & & & & & & \\
\hline Year $\times$ grass & NS & $*$ & & & & & & \\
\hline
\end{tabular}

NS,*,***Nonsignificant or significant at $P \leq 0.05$ or 0.01 and nonsignificant, respectively.

Table 4. Height and number of flower stalks of Solidago rigida L. from 1992 to 1997.

\begin{tabular}{|c|c|c|c|c|c|c|c|c|}
\hline \multicolumn{3}{|c|}{ Plot treatment and trait measured } & 1992 & 1993 & 1994 & 1995 & 1996 & 1997 \\
\hline \multirow{2}{*}{ 'Texoka' } & Height (cm) & & 89 & 94 & 92 & 74 & 67 & 66 \\
\hline & Stalk no. & & 10.2 & 28.8 & 42.0 & 29.3 & 15.5 & 20.6 \\
\hline \multirow{2}{*}{ ' 378 ' } & Height $(\mathrm{cm})$ & & 93 & 99 & 91 & 48 & 62 & 59 \\
\hline & Stalk no. & & 9.0 & 28.7 & 43.8 & 27.6 & 15.5 & 16.9 \\
\hline \multirow[t]{2}{*}{ ' $315 ’$} & Height $(\mathrm{cm})$ & & 96 & 101 & 91 & 70 & 62 & 63 \\
\hline & Stalk no. & & 11.2 & 30.8 & 38.9 & 26.2 & 11.3 & 15.5 \\
\hline \multirow{2}{*}{ Blue grama } & Height $(\mathrm{cm})$ & & 92 & 95 & 86 & 66 & 61 & 64 \\
\hline & Stalk no. & & 6.8 & 21.3 & 33.0 & 21.0 & 12.3 & 16.6 \\
\hline \multirow[t]{2}{*}{ Blank } & Height $(\mathrm{cm})$ & & 100 & 100 & 95 & 86 & 86 & 72 \\
\hline & Stalk no. & & 13.6 & 37.3 & 47.5 & 40.6 & 34.0 & 27.7 \\
\hline Source & Flower stalk no. & $\mathrm{Ht}$ & & & & & & \\
\hline Year & $* *$ & $* *$ & & & & & & \\
\hline Grass & $* *$ & $* *$ & & & & & & \\
\hline Year $\times$ grass & $* *$ & $* *$ & & & & & & \\
\hline
\end{tabular}

${ }^{* * *}$ Significant at $P \leq 0.01$.

Table 5. Height and number of flower stalks of Salvia azurea Lam. from 1992 to 1997.

\begin{tabular}{|c|c|c|c|c|c|c|c|c|}
\hline \multicolumn{3}{|c|}{ Plot treatment and trait measured } & 1992 & 1993 & 1994 & 1995 & 1996 & 1997 \\
\hline \multirow[t]{2}{*}{ 'Texoka' } & Height $(\mathrm{cm})$ & & 131 & 127 & 131 & 120 & 132 & 113 \\
\hline & Stalk no. & & 14.8 & 24.1 & 28.3 & 27.9 & 35.0 & 27.8 \\
\hline \multirow[t]{2}{*}{ ' 378 ' } & Height $(\mathrm{cm})$ & & 123 & 137 & 136 & 123 & 141 & 112 \\
\hline & Stalk no. & & 16.5 & 28.8 & 44.8 & 40.3 & 60.3 & 34.8 \\
\hline \multirow[t]{2}{*}{ ' 315 ' } & Height $(\mathrm{cm})$ & & 125 & 141 & 144 & 136 & 168 & 129 \\
\hline & Stalk no. & & 17.1 & 29.5 & 40.2 & 44.2 & 62.0 & 44.2 \\
\hline \multirow[t]{2}{*}{ Blue grama } & Height $(\mathrm{cm})$ & & 134 & 151 & 145 & 132 & 145 & 123 \\
\hline & Stalk no. & & 13.7 & 26.3 & 43.7 & 39.7 & 59.3 & 51.0 \\
\hline \multirow[t]{2}{*}{ Blank } & Height $(\mathrm{cm})$ & & 141 & 145 & 137 & 132 & 159 & 125 \\
\hline & Stalk no. & & 17.6 & 35.3 & 59.0 & 58.8 & 75.8 & 47.6 \\
\hline Source & Flower stalk no. & $\mathrm{Ht}$ & & & & & & \\
\hline Year & $* *$ & $* *$ & & & & & & \\
\hline Grass & $* *$ & $* *$ & & & & & & \\
\hline Year $\times$ grass & $* *$ & $*$ & & & & & & \\
\hline
\end{tabular}

${ }^{*, * *}$ Significant at $P \leq 0.05$ or 0.01 , respectively.

on observations of growth habit and reseeding in these two studies, would include L. punctata, E. angustifolius, L. squarrosa, S. rigida, R. pinnata, C. serrulatus, $P$. gracilis, $P$. grandiflorus, and $L$. incisum. Salvia azurea survived well but was aggressive and crowded out the grasses. The only grass used, S. scoparium, didwell. However, it did reseed greatly, a trait which should be a note of caution.

With care in selecting species, a warmseason, short-grass prairie can be established using wildflower transplants. Transplants offer an opportunity to establish a short-grass prairie with relative ease, resulting in a planting with plants that complement each other.

\section{Literature Cited}

Aldrich, J.H. 2002. Factors and benefits in the establishmen of modest-sized wildflower plantings: A review. Native Plants J. 3(1):67-86.

Grantz, D.A., D.L. Vaughn, R.J. Farber, B. Kim, L. Ashbaugh, T. Vancuren, R. Campbell, D. Bainbridge, and T. Zink. 1998. Transplanting native plants to revegetate abandoned farmland in the western Mojave Desert. J. Envir. Qual. 27:96-97.

Lindgren, D. and E. Wilde. 2003. Growing Penstemon: Species, cultivars and hybrids. Amer. Penstemon Soc. Infinity Publ., Haverford, Pa.

Phillips Petroleum Co. 1959. Native grasses, legumes and forbs. Sect. 1 and 3 of a series on pasture and range plants. Phillips Petroleum Co., Bartlesville, Okla.

Riordan, T.P., J. Johnson-Cicalese, F.P. Baxendale, M.C. Engelke, R.E. Gaussoin, G.L. Horst, and R.C. Shearman. 1995. Registration of ' 315 ' buffalograss. Crop
Sci. 35:1206

Salac, S.S., P.N. Jensen, J.A. Dickerson, and R.W. Gray, Jr. 1978. Wildflowers for Nebraska landscapes. Univ. Nebr. Inst. Agr. Natl. Res. Misc. Publ. 35.

SAS Institute. 1999. SAS system for Windows, Version 8. SAS Inst., Cary, N.C.

Stubbendieck, J.R., J.T. Nichols, and K.K. Roberts. 1985. Nebraska range and pasture grasses. Univ. Nebr. Coop. Ext. E.C. 85-170.

Thomas, A.L. and D. Schrock. 2004. Performance of 67 native midwestern U.S. perennials in a low-maintenance landscape. HortTechnology 14(3):381-388.

Todd, K. 2005. From this place, for this place: designing with native plants. 2005 Great Plains gardener. Nebr. Statewide Arboretum. Univ. Nebr., Lincoln.

Zajicek, J.M., R.K. Sutton, and S.S. Salac. 1986. Direct seeding of selected forbs into an established grasslands. HortScience 21:89-91. 